\title{
A BIZTONSÁGTUDATOSSÁG A DIGITÁLIS KOMPETENCIA TÜKRÉBEN
}

\section{SECURITY AWARENESS IN CONTEXT OF DIGITAL COMPETENCE}

\author{
Nyikes Zoltán \\ Óbudai Egyetem, Biztonságtudományi Doktori Iskola, 1081 Budapest, Népszínház \\ utca 8.fszt.46.nyikes.zoltan@mil.hu
}

\begin{abstract}
The author presents the digital competence and awareness of the security relationship between the publications. The author presents the security awareness-raising the possibility of digital competence. The author presents the development of a knowledge-based society through some important digital competence plays an increasingly important role. After that, the author presents the Smartphone applications by testing your security awareness and the existence of the digital competence low among users.
\end{abstract}

Keywords: security awereness, digital competence, smartphone, application, digital literacy.

\section{Összefoglalás}

A publikációban a szerző bemutatja a digitális kompetencia és a biztonságtudatosság kapcsolatát. Rávilágít a biztonságtudatosság erösítésének lehetőségére a digitális kompetencia növelésével. A szerző a tudás alapú társadalom fejlődésének néhány fontos pontjának vizsgálatával mutatja be a digitális kompetencia egyre fontosabb szerepét a jelenlegi társadalmi berendezkedésben. Majd az okostelefon alkalmazások vizsgálatával mutatja be a biztonságtudatosság és a digitális kompetencia alacsony meglétét a felhasználók körében.

Kulcsszavak: biztonságtudatosság, digitális kompetencia, okostelefon, alkalmazás, digitális irástudás.

\section{A digitális javak}

Az információ, avagy tudás alapú társadalom résztvevői részérôl az egyik leg alapvetőbb elvárása a társadalom irányába, hogy biztosítsa számukra a javakat. Ezek a javak jelen esetben digitális javak, úgy, mint elektronikus kereskedelem, banki ügyintézés, oktatás, ügyintézés és még sorolhatnánk. A társadalom részéről viszont alapvető elvárás az egyes tagjaival szemben, hogy azok a részükre biztosított digitális javakat elérjék, használják, és boldoguljanak vele, tegyék jobbá az életüket. Természetesen mindezt úgy, hogy az mindenki számára megnyugtatóan biztonságos le- gyen. Az egyén ugyan olyan felelős azért, hogy a részére biztosított javakat el tudja érni, mint maga a társadalmat irányító vezetés. Tehát nem mondható el az, hogy az állam feladata kizárólagosan a lakosság ilyen irányú képességének növelése, mert a kormányzati törekvések mind hiábavalóak, a társadalmi elvárások teljesítése érdekében, hogyha az egyén nem tesz semmit azért, hogy a célját elérje.

\subsection{A digitális jólét}

Az egyén kötelessége, hogy megtanulja használni azokat a közmüveket amelyek a jólétét szolgálják. A 20. században az iparosításnak köszönhetően az emberek számára elérhetővé vált a villamoshálózat, a vezeté- 
kes ivóvíz, a vezetékes földgáz, a csatornahálózat, a telefonhálózat. Majd a 20. százaz végén megjelent a legnagyobb közcélú informatikai hálózat, az internet. Az internet infrastruktúráján pedig a 20 éve nagy penetrációval bíró világháló mindenki rendelkezésére áll.

Az elmúlt fél évszázadban, ami az informatika igazi robbanásszerü fejlődését hozta magával, amely az információs rendszerek terjedését generálta, az emberek egyre szélesebb tábora találkozott a mindennapjaiban a számítógép-rendszerekkel. Szélesedett az oktatási paletta is ezen a területen. Az internet terjedését a már korábban említett világháló az úgy nevezett WorldWideWeb megjelenése segítette. Aztán a kétezres évek elején, közepén megjelentek az első okos (smart) telefonok, melyek alkalmasak voltak az internet elérésre. Természetesen ehhez a mobil szolgáltatók és a kábel tv szolgáltatók hatalmas fejlesztésére is szükség volt. Azzal, hogy mindenütt megjelent az informatika, azzal az életünk lett megkönnyítve. Gyorsabban, olcsóbban, egyszerübben tudunk ügyintézni, vásárolni, bankolni, kapcsolatot tartani távoli és közeli ismerőseinkkel, családunkkal, barátainkkal.

\section{A generációs szakadék}

Ahogy a technika fejlődött, a generációk is hozzá alkalmazkodva változtak. A mai Y és $\mathrm{Z}$ generáció már mondhatni „digitális bennszülöttek". Számukra az információs technológia jelenléte teljesen természetes, mint ahogy ezen cikk írójának - aki még az $X$ generációba tartozik - a villamos energia, a vezetékes víz. De nem csak az Y és $Z$ generációk életét hivatott megkönnyíteni az információs technológia, hanem az összes generációnak, mint ahogy az összes olyan közmü, amely az életünk konformizálását segíti, és minden generáció igénybe is veszi azokat.

Téves az az elképzelés, hogy ma már minden gyerek ért a számítógépekhez, mobilokhoz. Bizonyos szinten valóban igaz, de a biztonságról legtöbbször fogalmuk sincs. Az informatika, a digitális írástudás nem veleszületett adottság, hanem olyan képesség, amit meg kell szerezni. A British Computer Society által készített felmérés szerint a munkaadók csupán 52 százaléka vélekedik úgy, hogy munkatársai megfelelö digitális készségekkel rendelkeznek. Németországban és Ausztriában végzett kutatások pedig azt mutatják, hogy sokan alapvető műveletek elvégzésére sem képesek. Érdemes tudatosítani azt, hogy valaki képes kezelni az okostelefont és a közösségi oldalakon beszélget a barátaival, az még közel sem jelenti, hogy digitális írástudó. Egy olasz egyetemen végzett felmérés szerint az egyetemisták 42 százaléka nincs tisztában a free Wi-Fi veszélyeivel, 40 százalékuk nem védi pin-kóddal a telefonját, és 50 százalékuk minden ellenőrzés nélkül bármit letölt a gépére. Az International Computer and Information Literacy Study (ICILS) 60 ezer fiatal körében elvégzett felmérése szerint a megkérdezettek 17 százaléka a legalapvetőbb elvárásoknak sem felel meg, és csupán 2 százalék rendelkezik a tudatos eszközhasználathoz szükséges magas fokú tudással. [1]

\subsection{A kompetencia}

Olyan - ismereteket, készségeket, képességeket, személyiségjegyeket és attitüdöket tartalmazó - komplex rendszer amely

- képessé,

- kompetenssé teszi birtoklóját arra, hogy

- különböző helyzetekben,

- összetett,

- életszerü feladatok megoldásában eredményesen,

- hatékonyan cselekedjék [2].

\subsection{A digitális kompetencia}

$\mathrm{Az}$ információs és kommunikációs technológiák alkalmazásával kapcsolatos készségek a legalapvetőbb szinten a multimédiás technológiájú információk keresé- 
sét, értékelését, tárolását, létrehozását, bemutatását és átadását, valamint az internetes kommunikációt és a hálózatokban való részvétel képességét foglalják magukban [3].

\subsection{A digitális írástudás}

A digitális írástudás tudatosság, beállítódások és képességek olyan együttese, amely lehetővé teszi, hogy megfelelően és biztonságosan használjuk a digitális eszközöket és intézményeket a digitális források azonosítására, elérésére, kezelésére, integrálására, értékelésére és szintetizálására, továbbá új tudás és médiamegnyilvánulások létrehozására, valamint arra, hogy másokkal kommunikáljunk és reflektáljunk erre a folyamatra [4].

\subsubsection{A digitális írástudás fontossága}

- A 15 évnél idősebbek 40,2\%, 3 millió ember digitálisan nem kompetens Magyarországon;

- A másik 7 millió se az, mert nem használ olyan digitális tartalmakat ami kimeríti a digitális írástudás keretét;

- Félnek felfedezni a digitális világot, nem alakul ki a digitális készség [5].

\section{A biztonságtudatosság és a digi- tális kompetencia}

Ahhoz, hogy a kínálkozó infokommunikációs technológiákat mindenki használja, és jól használja, biztonságosan és hatékonyan, ahhoz a társadalom minden rétegének rendelkeznie kellene megfelelö mértékü digitális kompetenciával.

\subsection{A top 10}

A fenti állításunkat támasztja alá az, hogy a 10 legnépszerübb ingyenes mobiltelefon alkalmazásokat vizsgáltuk meg a három legnépszerübb mobil operációs rendszerre fejlesztett alkalmazások közül.

Az ,almás” operációs rendszer legnépszerübb ingyenes alkalmazásai között 2 játékalkalmazás, 2 chatalkalmazás, 2 közös- ségi oldal alkalmazás, 1 mozifilm megosztó, 1 zene megosztó, 1 közösségi videó megosztó alkalmazás volt és csak 1 oktatást segítő alkalmazás volt. Érdekesség, hogy csak a 25. helyen volt az első ekereskedelmi alkalmazás. Bármi féle biztonsági alkalmazás az eső százban nem is fordult elö [6].

A ,robotos” operációs rendszer esetében az ingyenes első tízben kicsit már jobb ugyan a helyzet, mivel ott 2 játékalkalmazás mellet, 3 közösségi oldal alkalmazás, 2 chat alkalmazás, 1 anitvírus, 1 karbantartó, és egy közösségi közlekedés alkalmazása volt [7].

Az ,ablakos” operációs rendszert használók az ingyenes alkalmazások közül 1 közösségi oldalalkalmazás, 1 hír- és 1 idöjárás alkalmazás, 1 videó lejátszó és 1 könyvolvasó alkalmazás, 1 online film és 1 online rádió alkalmazás, 1 internet telefon alkalmazás, 1 névnap emlékeztető alkalmazás és 1 nyelvoktató alkalmazás volt. A felmérés során az operációs rendszer beépített alkalmazás áruház szoftverét használtam.

A felmérésből és az abból készült 1. ábrából kitünik, hogy mind három operációs rendszer felhasználóinak a körében megtalálható az ingyenes applikációk között a közösségi médiához kapcsolódnak, illetve a kapcsolattartáshoz szükséges kommunikációs applikációk. A játék alkalmazások már megosztják a felhasználókat. A különböző segédprogramok a két véglet és a köztes átmenetet tükrözik, ahogyan az online média alkalmazások használata is. Végül látható, hogy az oktató programok előfordulása nagyon kicsi, ahogyan a karbantartó és antivírus megoldásoké is. A fenti kimutatás jól tükrözi, hogy a felhasználók az okostelefonjaikat inkább a szórakozás valamilyen formájára használják, a tanulással szemben. Nagyon lesújtó képet mutat a biztonság tudatosság is a biztonsági alkalmazások használata tekintetében. 


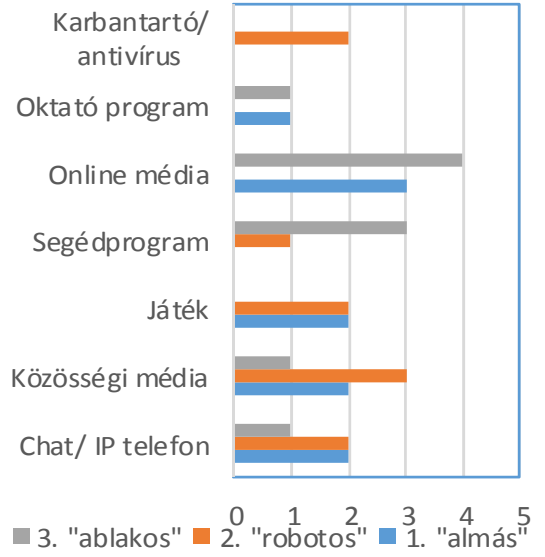

1.ábra. TOP 10 ingyenes alkalmazások eloszlása (készitette: a szerzö)

\section{Következtetések}

A biztonságtudatosság és a digitális kompetencia összefüggése jól látható. Véleményünk szerint a biztonságtudatosságot a digitális kompetencia erősítésével lehetne növelni és fordítva. Amennyiben az emberek tudatosabbak lennének a biztonság területén, abban az esetben a digitális kompetenciájuk is magasabb lenne. A kérdés az, hogy melyik oldalról megközelítve lehetne hatékonyabban célt érni. Az emberek nagyon kényelmesek és nem szeretnek olyan dolgokra áldozni, amelyek a vélt haszna alacsony, amilyen a biztonság kérdése. A digitális írástudás széleskörü elterjesztésére eddig volt bő 20 évünk, és a fenti számokból kitünik, hogy ez nem igazán sikerült. Az iskolai informatikai oktatás sok helyen a minimálisnál is alacsonyabb, mert maguk a tanárok se kompetensek a digitális világban.
A megoldás valószínüleg egy több irányú hiányosság-felszámolás lenne. Mind két irányból megindított felszámolási akció, valószínüleg hatékony lenne és a végeredményt sokkal hamarabb el lehetne érni, mint azt gondolnánk.

\section{Szakirodalmi hivatkozások}

[1] DigitalHungary: Fogalmunk sincs róla mi az a digitális írástudás, 2015. február 09., http://www.digitalhungary.hu/evolution/Fogalmunk-sincs-rola-mi-az-adigitalisirastudas/1748/\#sthash.eVmwNQTS.dpuf, letöltve: 2015. 12. 08.

[2] Klenovitsné Zóka Tünde: Digitális nemzedék, Digitális kompetencia, http://janus.ttk.pte.hu/tamop/tananyagok/digit alis_nemzedek/digitlis_kompetencia.html, letöltve: 2015. 12. 07.

[3] Az egész életen át tartó tanuláshoz szükséges kulcskompetenciák, 2009. jún. 17., https://www.ofi.hu/tudastar/nemzetkozikitekintes/egesz-eleten-at-tarto, letöltve: 2015. 12. 07.

[4] Koltay Tibor: Médiamüveltség, médiairástudás, digitális irástudás http://www.mediakutato.hu/cikk/2009_04_tel 108 mediamuveltseg_digitalis_irastudas, letöltve: 2015. 12.05.

[5] Zoltan Nyikes, Zoltan Rajnai: Big Data, As Part of the Critical Infrastructure, SISY 2015, IEEE 13th International Symposium on Intelligent Systems and Informatics, Serbia, Zrenjanin, 2015., pp. 217-222. ISBN:978-1-4673-9388-1

[6] iTunes Charts, http://www.apple.com/itunes/charts/freeapps/, letöltve: 2016. 01. 23.

[7] Google Play: Legnépszerübbek Alkalmazások kategóriában, https://play.google.com/store/apps/collection/ topselling_free, letöltve: 2016.01.23. 